\title{
MODELOWANIE OBCIAŻEŃ DYNAMICZNYCH W FORMIE PRZYSIADÓW NA KŁADKACH DLA PIESZYCH
}

\begin{abstract}
Konstrukcje budowlane charakteryzujące się zwiększoną podatnością dynamiczną i możliwością występowania drgań odczuwalnych przez ich użytkowników narażane są często na intencjonalne wzbudzanie drgań przez osoby wykonujące podskoki lub przysiady. Obciążenia dynamiczne tego typu wystąpić mogą m.in. na: kładkach dla pieszych, trybunach stadionowych, stropach budynków (podczas wydarzeń sportowo-rekreacyjnych, dyskotek, koncertów). W referacie przedstawiono charakterystykę obciążeń dynamicznych w formie sił reakcji podłoża generowanych podczas ciągłych, rytmicznych przysiadów wykonywanych przez jedną osobę wraz z propozycją modeli matematycznych tych obciążeń. Zaproponowane modele opracowano w oparciu o wyniki badań laboratoryjnych sił reakcji podłoża i wstępnie zweryfikowano w drodze dynamicznych analiz numerycznych oraz badań terenowych przykładowych kładek dla pieszych. Wyniki analiz i badań potwierdziły poprawność i skuteczność stosowania modeli w celu wyznaczania wartości sił reakcji podłoża powstających podczas ciągłych, rytmicznych przysiadów oraz ustalania wartości odpowiedzi dynamicznej konstrukcji.
\end{abstract}

Słowa kluczowe: przysiady, drgania, podatność, siły reakcji podłoża, odpowiedź dynamiczna, kładki, stropy, trybuny

\section{Wprowadzenie}

W przypadku konstrukcji budowlanych odznaczających się podwyższonym stopniem podatności dynamicznej, w sytuacjach występowania drgań pionowych tych konstrukcji, obciążenia dynamiczne w postaci sił reakcji podłoża ( $G R F$ - Ground Reaction Forces) powstających podczas rytmicznych podskoków lub przysiadów są obciążeniami charakteryzującymi się dużym prawdopodobieństwem wystąpienia. Użytkownicy odczuwający drgania konstrukcji (osoby idące lub stojące na konstrukcji), chcąc sprawdzić czy ich odczucia są rzeczywiste i poprawne, często rozpoczynają intencjonalne (celowe) wzbudzanie drgań konstrukcji wykonując podskoki lub przysiady.

\footnotetext{
${ }^{1}$ Marek Pańtak, Politechnika Krakowska, Katedra Budowy Mostów i Tuneli, ul. Warszawska 24, 31-155 Kraków; tel. (12) 628-29-13; mpantak@pk.edu.pl.
} 
Oddziaływania dynamiczne w formie przysiadów okazują się typem obciążeń równie lub bardziej groźnym od podskoków pomimo, iż wartości $G R F$ generowane podczas przysiadów osiągają wartości mniejsze niż $G R F$ powstające podczas podskoków. Obciążenia dynamiczne w formie przysiadów pozwalają na zachowanie ciągłego kontaktu osoby wymuszającej drgania z konstrukcją i dzięki temu szybszą synchronizację obciążenia z drgającą konstrukcją. Prowadzi to do wzbudzania amplitud drgań konstrukcji równie dużych lub niekiedy większych niż amplitudy powstające podczas podskoków.

Obciążenia dynamiczne w formie przysiadów mogą być zaliczone do wyjątkowych obciążeń dynamicznych konstrukcji pozwalających wyznaczyć maksymalne wartości amplitud drgań. W analizach dynamicznych konstrukcji narażonych na wzbudzanie drgań $\mathrm{w}$ formie przysiadów najistotniejsza jest pionowa składowa sił reakcji podłoża $(V G R F)$ powstających podczas przysiadów.

\section{Przysiady - cechy charakterystyczne}

Jednym z parametrów charakteryzujących przysiady jest ich głębokość wyrażana wartością kąta ugięcia kolan $\alpha$. Niesformalizowany dotychczas podział przysiadów, stosowany przez trenerów sportowych, wyodrębnia: przysiady częściowe $\left(\alpha=0-70^{\circ}\right.$ (najczęściej $\left.\alpha \approx 40^{\circ}\right), \alpha=0^{\circ}$ - nogi wyprostowane (rys. 1a)), półprzysiady $\left(\alpha=70-100^{\circ}\right)$, przysiady pełne (przysiady głębokie, $\alpha>100^{\circ}$ ) [1] (różne wartości graniczne kąta $\alpha$ mogą być definiowane przez różnych autorów, ich wartości mieszczą się jednak w podanych przedziałach).

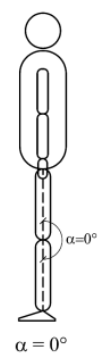

a)

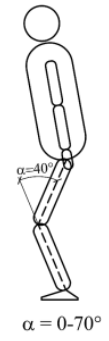

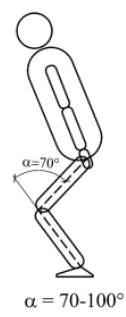

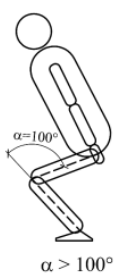

b)

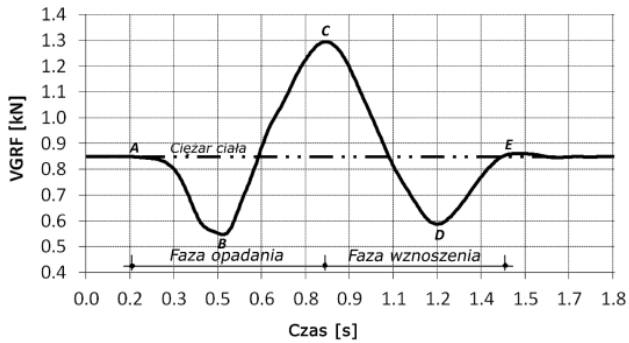

Rys. 1. Wybrane parametry przysiadów: a) kąt ugięcia kolan podczas przysiadów częściowych, półprzysiadów i przysiadów pełnych (głębokich), b) pionowa składowa siły reakcji podłoża (VGRF) powstająca podczas pojedynczego przysiadu

Fig. 1. Selected features of the squats: a) knee flexion angle during partial, half and deep squats, b) vertical component of the ground reaction force $(V G R F)$ generated during single partial squat

Podczas wykonywania przysiadu siła reakcji podłoża $V G R F$ przekazywana jest na podłoże podczas dwóch faz ruchu: fazy opadania i fazy wznoszenia (rys. 1b). W początkowym etapie fazy opadania (inicjacja ruchu ciała w kierunku ku dołowi, kompensacja luzów w stawach kończyn dolnych, napięcie mięśni) 
nacisk stóp na podłoże maleje, wartość $V G R F$ maleje poniżej wartości ciężaru ciała $G$ osoby wykonującej przysiad (rys. 1 b odcinek $A-B, V G R F<G$ ). W dalszym etapie fazy opadania nacisk stóp na podłoże wzrasta, wartość $V G R F$ wzrasta powyżej ciężaru ciała $G$ (rys. 1 b odcinek $B-C, V G R F>G$ ). Wartość maksymalna $V G R F$ występuje w chwili osiągnięcia przez środek ciężkości ciała najniższego punktu swojej trajektorii w fazie opadania (rys. 1b punkt $C$ ). Po osiągnięciu najniższego położenia rozpoczyna się ruch środka ciężkości ciała ku górze - faza wznoszenia (osoba wykonując przysiad wstaje z przysiadu). Podczas fazy wznoszenia wartość $V G R F$ maleje (rys. 1b odcinek $C-D$ ). W fazie tej przyspieszenie środka ciężkości ciała ma wartość ujemną w efekcie czego wypadkowa siła $V G R F$, będąca sumą dwóch sił: siły wynikającej z masy ciała osoby wykonującej przysiad oraz siły wynikającej z ruchu tej masy, maleje. W końcowym etapie fazy wznoszenia $V G R F$ ponownie osiąga wartość mniejszą od $G$. Minimalna wartość $V G R F$ (rys. 1b punkt $D, V G R F<G$ ) występuje w chwili osiągnięcia przez środek ciężkości ciała najwyższego punktu swojej trajektorii. W końcowym etapie przysiadu ruch ciała ustaje, mięśnie zostają rozluźnione, ciało nieznacznie opada na podłoże, nacisk stóp na podłoże lekko wzrasta, wartość $V G R F$ osiąga wartość ciężaru ciała osoby wykonującej przysiad $G$ (rys. 1b odcinek $D-E, V G R F=G$ ).

Na rys. $1 \mathrm{~b}$ przedstawiono przykładowy wykres $V G R F$ powstającej podczas pojedynczego przysiadu. Rys. 2. przedstawia natomiast przykładowe wykresy $V G R F$ zarejestrowane podczas przysiadów wykonywanych w sposób ciągły, kolejno jeden za drugim przez dwie różne osoby, z różnymi częstotliwościami $f_{s q}=1,70 \mathrm{~Hz}$ oraz $f_{s q}=2,40 \mathrm{~Hz}$.

a)

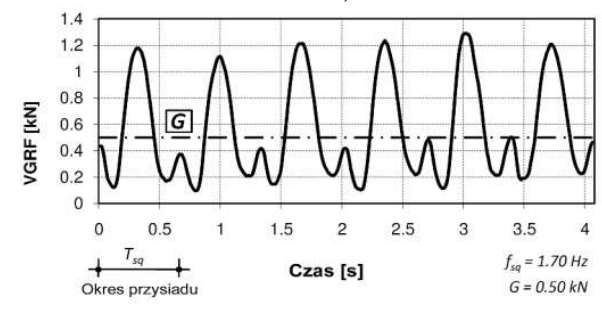

b)

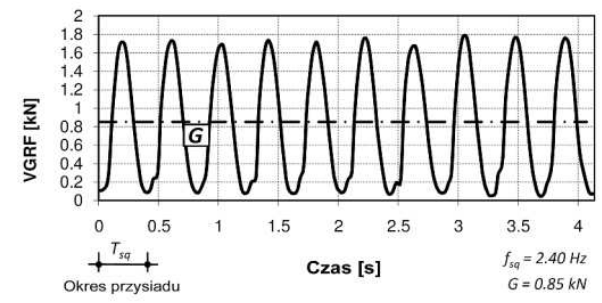

Rys. 2. Przykładowe wykresy $V G R F$ generowanych podczas a) przysiadów zakończonych pełnym wyprostowaniem nóg podczas fazy wznoszenia $f_{s q}=1,70 \mathrm{~Hz}, \mathrm{~b}$ ) przysiadów z częściowym prostowaniem nóg podczas fazy wznoszenia $f_{s q}=2,40 \mathrm{~Hz}$

Fig. 2. Examples of the $V G R F$ generated during a) squats with fully straightened legs at the end of the ascending phase of the squat $f_{s q}=1.70 \mathrm{~Hz}, \mathrm{~b}$ ) squats with partially straightened legs during ascending phase of the squat $f_{s q}=2.40 \mathrm{~Hz}$

Porównanie wykresów $V G R F$ przedstawionych na rys. 2. pozwala zauważyć wyraźną różnicę w przebiegu krzywych VGRF (rys. 2a - krzywa charakteryzuje się występowaniem małego wzniesienia pomiędzy kolejnymi przysiada- 
mi, rys. 2b - krzywa o kształcie sinusoidalnym). Różnica ta wynika z dwóch odmiennych technik wykonywania przysiadów. Techniki te różnią się między sobą stopniem prostowania nóg przez osoby wykonujące przysiady w końcowym etapie fazy wznoszenia.

Na rys. 2a przedstawiono krzywą $V G R F$ zarejestrowaną podczas przysiadów wykonywanych z pełnym prostowaniem nóg przez osobę wykonującą przysiady w końcowym etapie fazy wznoszenia. Rys. $2 \mathrm{~b}$ przedstawia natomiast krzywą $V G R F$ zarejestrowaną w przypadku przysiadów wykonywanych z częściowym prostowaniem nóg podczas fazy wznoszenia. Możliwość pełnego prostowania nóg podczas fazy wznoszenia zależna jest od indywidualnych predyspozycji osoby wykonującej przysiady oraz od częstotliwości przysiadów i głębokości ich wykonywania (stopnia ugięcia kolan).

Kształt krzywej $V R G F$ zarejestrowanej podczas przysiadów kończonych pełnym wyprostowaniem nóg w fazie wznoszenia charakteryzuje się występowaniem pośredniego małego wierzchołka pojawiającego się pomiędzy kolejno następującymi po sobie przysiadami, w końcowym etapie fazy wznoszenia. Zauważyć można częściowe podobieństwo krzywej $V R G F$ przedstawionej na rys. 2a do krzywej jaką uzyskać można poprzez zestawienie okresowo powtarzanych impulsów siły powstających podczas pojedynczego przysiadu, impulsów powtarzanych z okresem $T_{s q}=1 / f_{s q}$ (por. rys. 1b). Krzywa przedstawiona na rys. 2a nie jest jednak dokładną kopią impulsu siły powstającego podczas pojedynczego przysiadu. Zauważyć należy, iż końcowa wartość $V R G F$ występująca podczas pojedynczego przysiadu osiąga wartość $G$ ciężaru ciała osoby wykonującej przysiad $(V G R F=G)$. W przypadku przysiadów wykonywanych w sposób ciągły, kolejno jeden za drugim, gdy przysiady te wykonywane są bez odrywania stóp od podłoża i bez uderzenia pięt o podłoże, wartość $V G R F$ w miejscu pośredniego wierzchołka pomiędzy kolejnymi następującymi po sobie przysiadami nie osiąga wartości ciężaru ciała $G$ osoby wykonującej przysiady. Wartość ta zależna jest od częstotliwości przysiadów $f_{s q}$ i na ogół maleje wraz ze wzrostem tej częstotliwości. Zależy to jednak również od indywidualnych predyspozycji osoby wykonującej przysiady.

Krzywa $V G R F$ przedstawiona na rys. 2b zarejestrowana podczas przysiadów wykonywanych z częściowym prostowaniem nóg w fazie wznoszenia, gdy kolana osoby wykonującej przysiady pozostają lekko ugięte ,ma przebieg sinusoidalny (ruch ciała osoby wykonującej przysiady jest płynny, podobny do ruchu masy zawieszonej na sprężynie).

Maksymalna wartość VGRF osiągana podczas wykonywania częściowych przysiadów zależna jest od ciężaru ciała osoby wykonującej przysiady oraz od częstotliwości przysiadów i wynosi $F_{\max , s q} \approx(1,40-2,00) \cdot G$ - dla częstotliwości $f_{s q}<1,80 \mathrm{~Hz}$ oraz $F_{\max , s q} \approx(2,00-2,50)^{\cdot} G-$ dla częstotliwości $f_{s q} \geq 1,80 \mathrm{~Hz}$. Wartość ta jest mniejsza od maksymalnej warności VGRF powstającej podczas podskoków $F_{\text {max } j m p} \approx(2,50-4,50)^{\cdot} G$. Niemniej jednak, jak wspomniano wcześniej, obciążenia dynamiczne powstające podczas przysiadów mogą być równie 
lub bardziej groźne od obciążeń powstających podczas podskoków z powodu zachowania ciągłego kontaktu osoby wykonującej przysiady z konstrukcją i szybszej synchronizacji wymuszenia z drganiami obiektu. Efekt ten wymaga dalszych analiz i może ulegać zmianie w zależności od wartości częstotliwości wykonywania przysiadów lub podskoków.

Minimalna wartość $V G R F$ powstająca podczas częściowych przysiadów zależna jest, podobnie jak jej wartość maksymalna, od częstotliwości przysiadów i ciężaru ciała osoby wykonującej przysiady i wynosi $F_{\min , s q} \approx(0,30-0,50) \cdot G-$ dla częstotliwości $f_{s q}<1,80 \mathrm{~Hz}, F_{\min , s q} \approx(0,15-0,25) \cdot G$ - dla częstotliwości $f_{s q}=1,80-2,20 \mathrm{~Hz}$ oraz $F_{\text {min,sq }} \approx(0.05-0.15)^{\cdot} G-$ dla częstotliwości $f_{s q}=2,20-2,80 \mathrm{~Hz}$. Podczas wykonywania przysiadów VGRF nie osiąga wartości zerowej gdyż obie stopy zachowują ciągły kontakt z podłożem.

$\mathrm{Na}$ rys. 3. przedstawiono przykładowe wykresy znormalizowanych krzywych $V G R F / G$ powstających podczas częściowych przysiadów uzyskane na podstawie wyników badań laboratoryjnych przeprowadzonych przez autora z wykorzystaniem platformy dynamometrycznej Zebris FDM1.5 w zakresie częstotliwości $0,50-2,80 \mathrm{~Hz}$.

a)

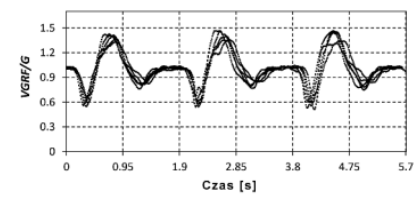

d)

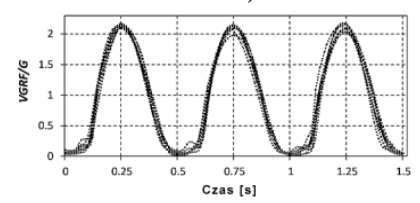

b)

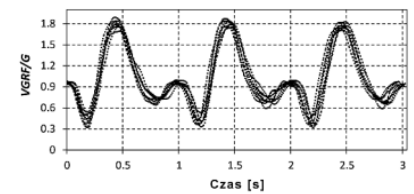

e)

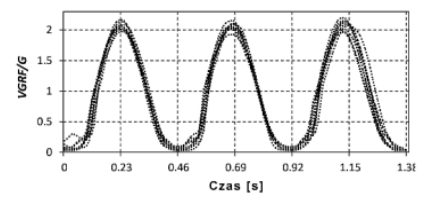

c)

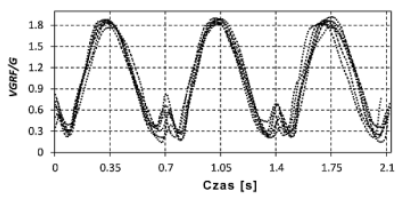

f)

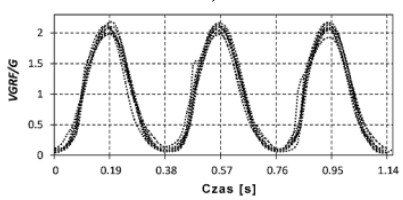

Rys. 3. Przykładowe wykresy znormalizowanych krzywych $V G R F / G$ powstających podczas częściowych przysiadów z różnymi częstotliwościami a) $f_{s q}=0,53 \mathrm{~Hz}$, b) $f_{s q}=1,00 \mathrm{~Hz}$, c) $f_{s q}=1,43$ $\mathrm{Hz}$, d) $f_{s q}=2,00 \mathrm{~Hz}$, e) $\left.f_{s q}=2,17 \mathrm{~Hz}, \mathrm{f}\right) f_{s q}=2,63 \mathrm{~Hz}$

Fig. 3. Examples of the graphs of normalized $V G R F / G$ curves generated during partial squats with different frequencies a) $f_{s q}=0.53 \mathrm{~Hz}$, b) $f_{s q}=1.00 \mathrm{~Hz}$, c) $f_{s q}=1.43 \mathrm{~Hz}$, d) $f_{s q}=2.00 \mathrm{~Hz}$, e) $\left.f_{s q}=2.17 \mathrm{~Hz}, \mathrm{f}\right) f_{s q}=2.63 \mathrm{~Hz}$

\section{Częściowe przysiady - modele obciążenia}

Uwzględniając wyniki badań VGRF opracowano modele obciążeń dynamicznych generowanych podczas częściowych przysiadów. Modele te zaproponowano dla dwóch przedziałów częstotliwości przysiadów $f_{s q} \leq 1.60 \mathrm{~Hz}$ oraz $f_{s q}>1.60 \mathrm{~Hz}$. Częstotliwość $f_{s q}=1.60 \mathrm{~Hz}$ przyjęto za graniczną częstotliwość przysiadów poniżej której możliwe jest swobodne i pełne prostowanie nóg pod- 
czas wykonywania przysiadów w ostatnim etapie fazy wznoszenia (krzywa $V G R F$ nie ma przebiegu sinusoidalnego). Dla $f_{s q}>1.60 \mathrm{~Hz}$ krzywa $V G R F$ zmienia kształt uzyskując przebieg sinusoidalny. Podkreślić należy iż wartość przyjętej częstotliwości granicznej zależna jest od indywidualnych predyspozycji osoby wykonującej przysiady oraz od częstotliwości przysiadów i głębokości ich wykonywania (stopnia ugięcia kolan) i może być większa.

Analizując krzywą przedstawioną na rys. $1 \mathrm{~b}$ i rys. $2 \mathrm{a}$ zauważyć można podobieństwo pojedynczego impulsu siły do wykresu funkcji $y=\operatorname{sinc}(x)=\sin (x) / x$ dla $x \neq 0$ oraz do wykresu funkcji trójkątnej $y=-\lambda \cdot|x|+\lambda$ wyznaczonych dla dodatnich i ujemnych wartości $x$ (rys. 4.).

a)

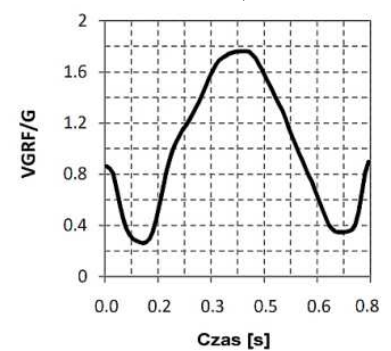

b)

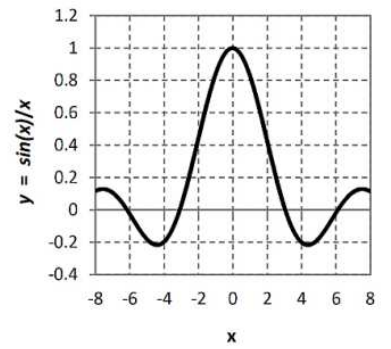

c)

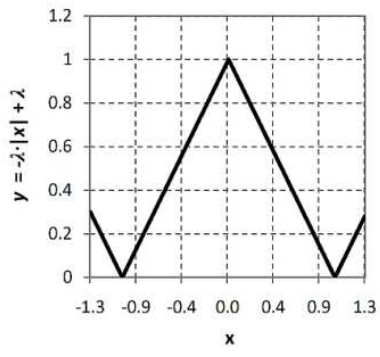

Rys. 4. Porównanie znormalizowanej krzywej $V G R F / G$ do przebiegu podstawowych funkcji matematycznych a) $V G R F / G$ dla pojedynczego przysiadu (pojedynczy impuls siły), b) wykres funkcji $y=\operatorname{sinc}(x)=\sin (x) / x, \mathrm{c})$ wykres funkcji $y=-\lambda \cdot|x|+\lambda$

Fig. 4. Comparison of the $V G R F / G$ curve with basic mathematical functions a) $V G R F / G$ generated during single squat (single force impulse), b) graph of the function $y=\operatorname{sinc}(x)=\sin (x) / x$, c) graph of the function $y=-\lambda \cdot|x|+\lambda$

Biorąc pod uwagę występujące podobieństwo krzywej VGRF do wspomnianych bazowych funkcji matematycznych zaproponowano dwa alternatywne modele obciążeń dynamicznych (1) i (2) dla przysiadów częściowych wykonywanych z częstotliwością $f_{s q}=1,00-1,60 \mathrm{~Hz}$ :

$$
F(t)=k_{1} G\left[0,5+k_{2} \frac{\sin \left(4 \pi f_{s q} t\right)}{t}\right]
$$

gdzie: $G$ - ciężar ciała osoby wykonującej przysiady [kN],

$f_{s q}-$ częstotliwość przysiadów $[\mathrm{Hz}]$,

$k_{l}$ - współczynnik:

$$
\begin{aligned}
& k_{l}=1,35 \text { dla } \mathrm{G}<0,70 \mathrm{kN}, \\
& k_{l}=1,00 \text { dla } \mathrm{G} \geq 0,70 \mathrm{kN},
\end{aligned}
$$


$k_{2}$ - współczynnik (rys. 5a):

$k_{2}=-0,06 \cdot f_{s q}+0,16 \mathrm{dla} f_{s q}=1,00-1,50 \mathrm{~Hz}$,

$k_{2}=0,07$ dla $f_{s q}=1,50-1,60 \mathrm{~Hz}$,

$t$ - krok czasowy [s], $t \in\left(-0,5 T_{s q}, 0,5 T_{s q}\right)$,

$T_{s q}$ - okres przysiadów $[\mathrm{s}], T_{s q}=1 / f_{s q}$,

lub

$$
F(t)=\left\{\begin{array}{l}
G\left(\lambda_{1} f_{s q}|t|-\lambda_{2}\right) \text { dla } t \in\left\langle-0,5 T_{s q},-0,4 T_{s q}\right\rangle \wedge \Delta t \in\left\langle 0,4 T_{s q}, 0,5 T_{s q}\right\rangle \\
G\left(0,4-3 \lambda_{3} f_{s q}|t|+\lambda_{3}\right) \text { dla } t \in\left(-0,4 T_{s q}, 0,4 T_{s q}\right)
\end{array}\right.
$$

gdzie: $G, f_{s q}, T_{s q}, t-$ jak w równaniu (1),

$\lambda_{1}, \lambda_{2}, \lambda_{3}-$ współczynniki (rys. 5b, c, d):

$$
\begin{aligned}
& \lambda_{1}=-7,5 f_{s q}+13,5 \text { dla } f_{s q}=1,00-1,40 \mathrm{~Hz}, \\
& \lambda_{1}=3,0 \text { dla } f_{s q}=1,40-1,60 \mathrm{~Hz}, \\
& \lambda_{2}=-3 f_{s q}+5,2 \text { dla } f_{s q}=1,00-1,40 \mathrm{~Hz}, \\
& \lambda_{2}=1,0 \text { dla } f_{s q}=1,40-1,60 \mathrm{~Hz}, \\
& \lambda_{3}=0,25 f_{s q}+1,15 \text { dla } f_{s q}=1,00-1,60 \mathrm{~Hz} .
\end{aligned}
$$

a)

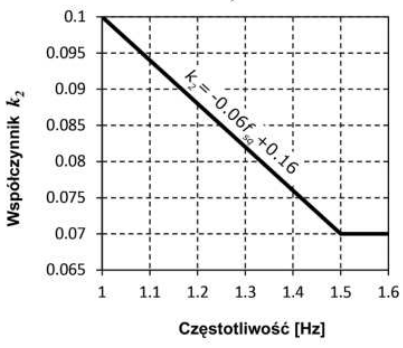

c)

d)
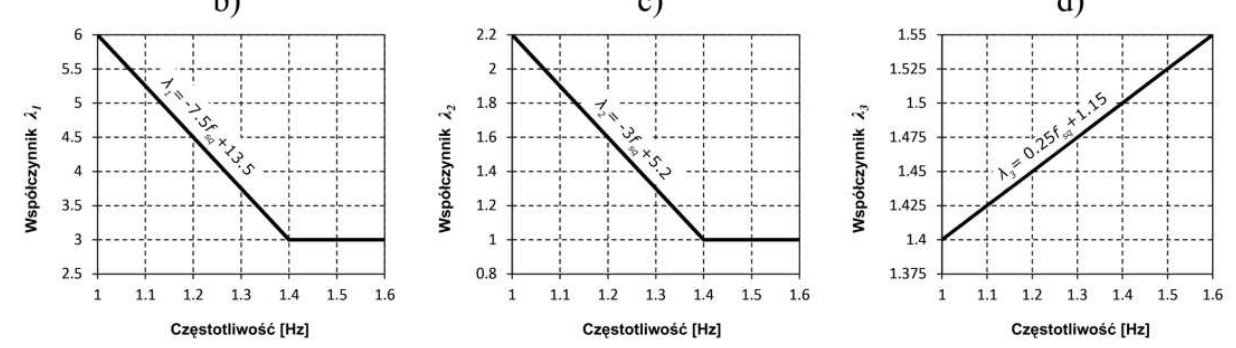

Rys. 5. Współczynniki: a) $k_{2}$ do równania (1), b) $\lambda_{1}$ do równania (2), c) $\lambda_{2}$ do równania (2), d) $\lambda_{3}$ do równania (2)

Fig. 5. Coefficients: a) $k_{2}$ for equation (1), b) $\lambda_{1}$ for equation (2), c) $\lambda_{2}$ for equation (2), d) $\lambda_{3}$ for equation (2) 
Dla przysiadów wykonywanych z częstotliwością $f_{s q}>1,60 \mathrm{~Hz}$ zaproponowano model obciążenia (3):

$$
F_{V G R F}(t)=G\left[1,1+\sin \left(2 \pi f_{s q} t\right)\right]
$$

gdzie: $G, f_{s q}, T_{s q}-$ jak w równaniu (1),

$t$ - krok czasowy, $t \geq 0$.

Na rys. 6. przedstawiono porównanie krzywych $V G R F / G$ wyznaczonych za pomocą równań (1), (2) oraz (3) w odniesieniu do krzywych $V G R F / G$ zarejestrowanych podczas badań laboratoryjnych dla różnych częstotliwości przysiadów.

a)

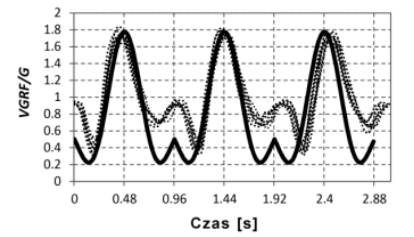

d)

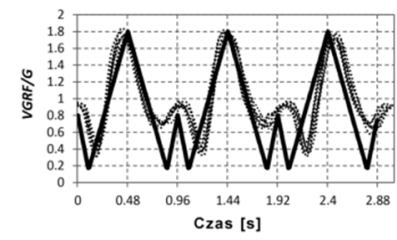

g)

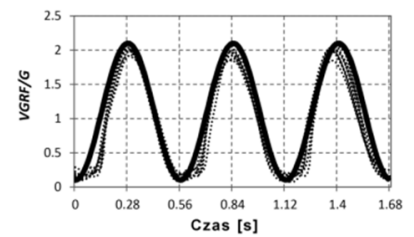

b)

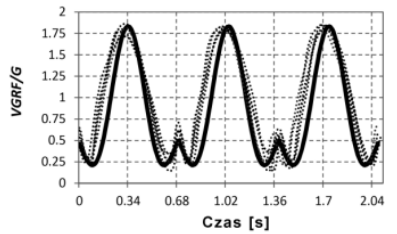

e)

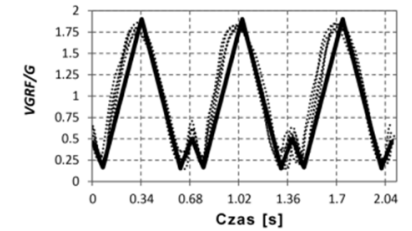

h)

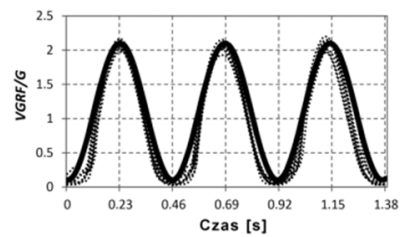

c)

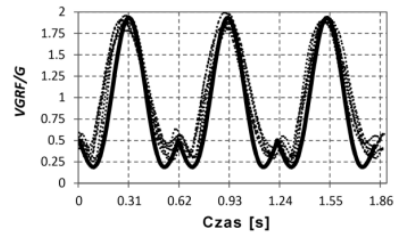

f)

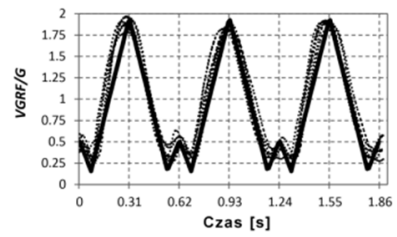

i)

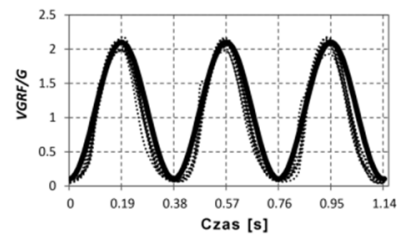

Rys. 6. Krzywe $V G R F / G$ wyznaczone za pomocą równań (1), (2) i (3) w odniesieniu do krzywych $V G R F / G$ zarejestrowanych podczas badań laboratoryjnych dla różnych częstotliwości przysiadów a), b), c) wg równania (1) dla częstotliwości $1,04 \mathrm{~Hz}, 1,47 \mathrm{~Hz}, 1,62 \mathrm{~Hz}$ odpowiednio, d), e), f) wg równania (2) dla częstotliwości 1,04 Hz, 1,47 Hz, 1,62 Hz odpowiednio, g), h), i) wg równania (3) dla częstotliwości $1,78 \mathrm{~Hz}, 2,17 \mathrm{~Hz}, 2,63 \mathrm{~Hz}$ odpowiednio

Fig. 6. The $V G R F / G$ curves calculated using equations (1), (2) and (3) in relation to $V G R F / G$ measured during laboratory tests for different squat frequency: a), b), c) equation (1) for frequency $1.04 \mathrm{~Hz}, 1.47 \mathrm{~Hz}, 1.62 \mathrm{~Hz}$ respectively, d), e), f) equation (2) for frequency $1.04 \mathrm{~Hz}, 1.47 \mathrm{~Hz}$, $1.62 \mathrm{~Hz}$ respectively, g), h), i) equation (3) for frequency $1.78 \mathrm{~Hz}, 2.17 \mathrm{~Hz}, 2.63 \mathrm{~Hz}$ respectively 
Inną propozycję modelu VGRF powstających podczas wykonywania przysiadów przedstawiono $\mathrm{w}$ pracy [2].

Model ten opracowany został $\mathrm{z}$ wykorzystaniem funkcji harmonicznej $\mathrm{z}$ thumieniem (4):

$$
F(t)=G\left[1+A \cos (\omega|t|-\varphi) e^{-|t| \delta}\right]
$$

gdzie: $G, t-$ jak w równaniu (1),

$A$ - amplituda składowej dynamicznej obciążenia,

$\omega$ - częstość kołowa impulsu siły, $\omega=2 \pi f_{s q}[\mathrm{rad} / \mathrm{s}]$,

$\varphi$ - przesunięcie fazowe, $\varphi=0,25$ (wartość stała),

$\delta$ - tłumienie,

Parametry $A$ i $\delta$ modelu wyznaczone zostały podczas badań sił $V G R F$ przy częstotliwości wymuszeń $f_{s q}=2,00 \mathrm{~Hz}$. W badaniach wzięły udział 33 osoby w wieku 22-24 lat. W wyniku badań otrzymano wartość średnią amplitudy składowej dynamicznej obciążenia $A_{\text {mean }}=1,33\left(A_{\min }=1,07, A_{\max }=1,52\right.$, wariancja $\operatorname{Var}(A)=0,128)$ oraz wartość tłumienia $\delta=4 \sqrt{T_{s q}}$. Ostatecznie równanie (4) zapisano w postaci równania (5) symulującego celowe obciążenie konstrukcji pochodzące od jednej osoby wykonującej przysiady, przyjmując typowy ciężar osoby $G=0,75 \mathrm{kN}$ oraz $A=1,3$ :

$$
F(t)=0,75 \cdot\left[1+1,3 \cos (4,8 \pi|t|-0,25) e^{-|t| \delta}\right]
$$

gdzie: $t-$ jak w równaniu (4),

$\delta$ - tłumienie, $\delta=4 \sqrt{T_{s q}},\left(T_{s q}\right.$ - okres przysiadów $)$.

Podkreślić należy, iż model (5) opracowano przy przyjęciu stałej wartości $G=0,75 \mathrm{kN}$ oraz wartości paramentów $A$ i $\delta$ wyznaczonych przy wymuszeniach $\mathrm{z}$ częstotliwością $f_{s q}=2,00 \mathrm{~Hz}$. Ponadto w równaniu (5) przyjęto wartość $\omega=2 \pi f_{s q}=4,8 \pi$ odpowiadającą przyjęciu wartości $f_{s q}=2,40 \mathrm{~Hz}$. Dla tak przyjętych parametrów modelu (5) uzyskano w [2] zgodność wyników symulacji sił $V G R F \mathrm{z}$ wynikami badań laboratoryjnych. Stosowanie modelu (5) w analizach dynamicznych charakteryzujących się innymi parametrami obciążeń dynamicznych może wymagać odpowiedniego dostrojenia parametrów modelu.

Na rys. 7. przedstawiono porównanie krzywych $V G R F / G$ wyznaczonych za pomocą równania (5) z krzywymi $V G R F / G$ uzyskanymi w niezależnych badaniach laboratoryjnych. W celu porównania wartości $V G R F$ wyznaczonych za pomocą modelu (5) ze znormalizowanymi krzywymi $V G R F / G$ uzyskanymi na podstawie badań, wartości $V G R F$ wyznaczone za pomocą modelu (5) zostały 
podzielone przez ciężar $G=0,75 \mathrm{kN}$ przyjęty w równaniu (5) jako wartość stała).

a)

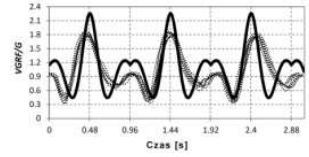

b)

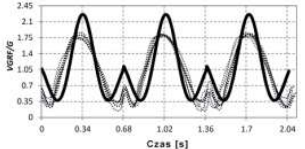

c)

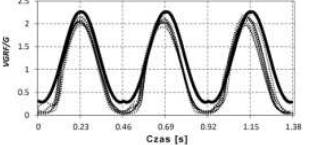

d)

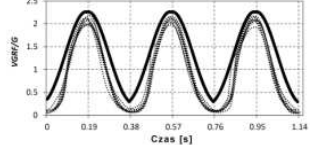

Rys. 7. Krzywe $V G R F / G$ wyznaczone za pomocą równania (5) dla $G=0.75 \mathrm{kN}$ w odniesieniu do krzywych $V G R F / G$ zarejestrowanych podczas badań laboratoryjnych dla różnych częstotliwości przysiadów a), b), c), d) $1.04 \mathrm{~Hz}, 1.47 \mathrm{~Hz}, 2.20 \mathrm{~Hz}, 2.63 \mathrm{~Hz}$ odpowiednio

Fig. 7. The $V G R F / G$ curves calculated using equation (5) for $G=0.75 \mathrm{kN}$ in relation to $V G R F / G$ measured during laboratory tests for different frequencies of the squats a), b), c), d) $1.04 \mathrm{~Hz}$, $1.47 \mathrm{~Hz}, 2.20 \mathrm{~Hz}, 2.63 \mathrm{~Hz}$ respectively

\section{Walidacja modeli obciążeń}

W celu sprawdzenie poprawności modeli obciążeń (1), (2), (3), (5) wykonano analizy dynamiczne oraz badania terenowe wybranych kładek dla pieszych przedstawionych na rys. 8 . Kładki te odznaczają się zwiększoną podatnością dynamiczną na wymuszenia pionowe oraz niskimi wartościami parametrów tłumienia drgań [3]. Ich częstotliwości drgań własnych pozwalają na łatwe wzbudzanie drgań podczas wykonywania przysiadów.

Analizowane konstrukcje zaprojektowane zostały jako kładki stalowe $\mathrm{z}$ dźwigarem $\mathrm{w}$ formie kratownicy przestrzennej. W analizach uwzględniono dwa warianty konstrukcyjne kładki w Bieczu (rys. 8c): kładkę stalową oraz kładkę zespoloną stalowo-betonową z pomostem betonowym gr. $15 \mathrm{~cm}$.

a)
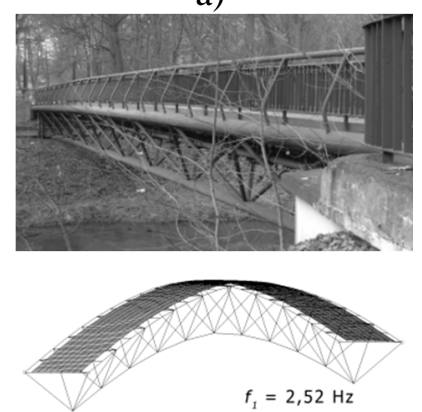

b)
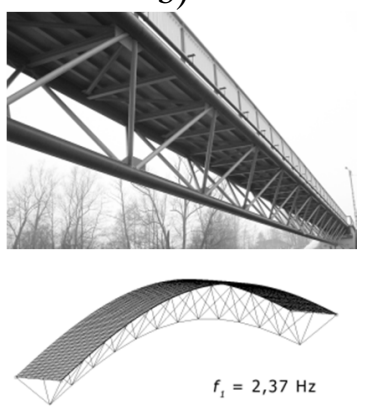

c)

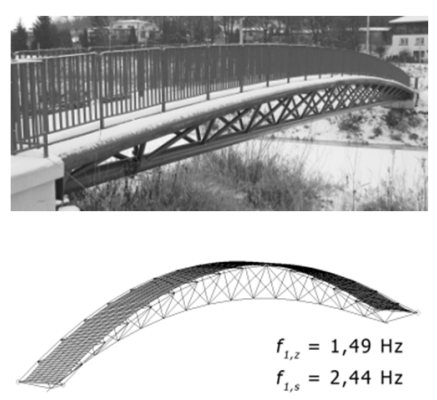

Rys. 8. Kładki dla pieszych a) w Sławięcicach $L_{t}=44,70 \mathrm{~m}, f_{l}=2,52 \mathrm{~Hz}$, b) w Osjakowie $\left.L_{t}=2 \times 50,0 \mathrm{~m}, f_{l}=2,37 \mathrm{~Hz}, \mathrm{c}\right)$ w Bieczu $L_{t}=47,00 \mathrm{~m}, f_{l, z}=1,49 \mathrm{~Hz}-$ konstrukcja zespolona, $f_{1, s}=2,44 \mathrm{~Hz}-$ konstrukcja stalowa

Fig. 8. Footbridges a) in Sławięcice $\left.L_{t}=44,70 \mathrm{~m}, f_{l}=2,52 \mathrm{~Hz}, \mathrm{~b}\right)$ in Osjaków $L_{t}=2 \times 50,0 \mathrm{~m}$, $\left.f_{l}=2,37 \mathrm{~Hz}, \mathrm{c}\right)$ in Biecz $L_{t}=47,00 \mathrm{~m}, f_{l, z}=1,49 \mathrm{~Hz}$ - composite structure, $f_{l, s}=2,44 \mathrm{~Hz}-$ steel structure 
Podstawowe parametry dynamiczne kładek (częstotliwość drgań własnych, logarytmiczny dekrement tłumienia drgań - LDT) oraz wartości odpowiedzi dynamicznych konstrukcji na wymuszenie drgań w postaci przysiadów wykonywanych przez jedną osobę określono w drodze badań terenowych (tab. 1.).

W celu oceny poprawności modeli obciążeń (1), (2), (3), (5) odpowiedź dynamiczną kładek wyznaczono również w drodze analiz numerycznych z wykorzystaniem przestrzennych modeli obliczeniowych konstrukcji. Wartość tłumienia drgań przyjęto $\mathrm{w}$ analizach zgodnie $\mathrm{z}$ wynikami badań terenowych. $\mathrm{W}$ przypadku kładki w Bieczu wartość logarytmicznego dekrementu tłumienia drgań (LDT) konstrukcji zespolonej stalowo-betonowej (rozpatrywanej jako teoretyczny/możliwy wariant rozwiązania konstrukcyjnego) przyjęto jak dla konstrukcji stalowej (por. zalecenia [4]).

Wartości odpowiedzi dynamicznych kładek (przyspieszenia drgań) określono dla czasu wzbudzania drgań wynoszącego 10 sek. Zbiorcze zestawienie wyników analiz numerycznych i badań terenowych przedstawiono w tab. 1.

Tabela 1. Wyniki badań terenowych i analiz numerycznych kładek

Table 1. Results of the field tests and numerical analyses of the footbridges

\begin{tabular}{|c|c|c|c|c|c|c|c|}
\hline \multirow[t]{2}{*}{ Kładka } & \multirow{2}{*}{$\begin{array}{c}\text { Model } \\
\text { obciążenia }\end{array}$} & \multicolumn{2}{|c|}{$\begin{array}{c}\text { Częstotliwość } \\
{[\mathrm{Hz}]}\end{array}$} & \multirow{2}{*}{$\begin{array}{c}G \\
{[\mathrm{kN}]}\end{array}$} & \multicolumn{2}{|c|}{$\begin{array}{l}\text { Przyspieszenie } \\
\text { po } 10 \mathrm{sek} .\left[\mathrm{m} / \mathrm{s}^{2}\right]\end{array}$} & \multirow{2}{*}{$\frac{L D T}{\text { Badania }}$} \\
\hline & & Analiza & Badania & & Analiza & Badania & \\
\hline \multirow{2}{*}{ Sławięcice } & (3) & \multirow{2}{*}{2,52} & \multirow{2}{*}{2,52} & \multirow{2}{*}{0,83} & 2,21 & \multirow{2}{*}{2,12} & \multirow{2}{*}{0,027} \\
\hline & (5) & & & & 2,19 & & \\
\hline \multirow{2}{*}{ Osjaków } & (3) & \multirow{2}{*}{2,37} & \multirow{2}{*}{2,37} & \multirow{2}{*}{0,75} & 2,63 & \multirow{2}{*}{2,52} & \multirow{2}{*}{0,010} \\
\hline & (5) & & & & 2,65 & & \\
\hline \multirow{2}{*}{$\begin{array}{c}\text { Biecz } \\
\text { (k. stalowa) }\end{array}$} & (3) & \multirow{2}{*}{2,43} & \multirow{2}{*}{2,44} & \multirow{2}{*}{0,75} & 2,15 & \multirow{2}{*}{2,07} & \multirow{2}{*}{0,044} \\
\hline & (5) & & & & 2,12 & & \\
\hline \multirow{4}{*}{$\begin{array}{c}\text { Biecz } \\
\text { (k. zespolona) }\end{array}$} & VGRF & \multirow{4}{*}{1,49} & \multirow{4}{*}{-} & \multirow{4}{*}{0,75} & 0,73 & \multirow{4}{*}{-} & \multirow{4}{*}{0,044} \\
\hline & $(1)$ & & & & 0,68 & & \\
\hline & (2) & & & & 0,64 & & \\
\hline & (5) & & & & 0,60 & & \\
\hline
\end{tabular}

W modelu obciążenia (5), w analizie kładki w Sławięcicach, przyjęto ciężar osoby wykonującej przysiady $G=0,83 \mathrm{kN}$ odpowiadający ciężarowi osoby wykonującej przysiady podczas badań terenowych (mnożnik 0,75 występujący w równaniu (5) zastąpiono mnożnikiem 0,83 ).

$\mathrm{Z}$ powodu braku możliwości wykonania badań terenowych zaproponowanego wariantu konstrukcyjnego kładki w Bieczu (konstrukcja zespolona), przyspieszenia drgań kładki zespolonej, wyznaczone za pomocą modeli obciążeń (1), (2) i (5), porównano z wartością przyspieszenia drgań uzyskaną w drodze obliczeń numerycznych wykonanych z wykorzystaniem sił $V G R F$ zarejestrowanych na platformie dynamometrycznej podczas badań laboratoryjnych dla przysiadów z częstotliwością $f_{s q}=1,49 \mathrm{~Hz}$ (tab. 1 ., model obciążenia $V G R F$ ). Wynik ten na- 
leży traktować jako orientacyjne oszacowanie wartości odpowiedzi konstrukcji pozwalające wstępnie ocenić efektywność modeli obciążeń (1), (2) i (5).

\section{Ocena modeli, wnioski i podsumowanie}

Przedstawione modele obciążeń dynamicznych (1), (2), (3) opracowane zostały na podstawie badań laboratoryjnych pionowych sił reakcji podłoża $(V G R F)$ generowanych podczas częściowych przysiadów wykonywanych przez jedną osobę. Badania przeprowadzono w zakresie częstotliwości przysiadów $f_{s q}=0,50-2,80 \mathrm{~Hz}$. Opracowane modele obciążeń (1), (2), (3) zaproponowano dla przedziału częstotliwości $f_{s q}=1,00-2,80 \mathrm{~Hz}$.

W procesie weryfikacji i walidacji modeli stwierdzono co następuje:

- w przedziale częstotliwości przysiadów $f_{s q}=1,20-2,80 \mathrm{~Hz}$ krzywe VGRF wyznaczone z wykorzystaniem modeli (1), (2), (3) dobrze odzwierciedlają przebieg krzywych $V G R F$ zarejestrowanych podczas badań laboratoryjnych (por. rys. 6.);

- w przedziale częstotliwości przysiadów $f_{s q}<1,20 \mathrm{~Hz}$ (przysiady wykonywane w wolnym i bardzo wolnym tempie) wymagana jest modyfikacja zaproponowanych modeli lub opracowanie nowego modelu. $\mathrm{Z}$ powodu asymetrycznego kształtu krzywych VGRF generowanych podczas przysiadów wykonywanych w wolnym tempie zaproponowane modele (1) i (2), wykorzystujące funkcje matematyczne o wykresach symetrycznych względem osi pionowej, niedokładnie odtwarzają przebieg krzywych $V G R F$. Znajomość modeli $V G R F$ dla przysiadów wykonywanych $\mathrm{w}$ wolnym tempie jest istotna w przypadku analiz dynamicznych wiszących i podwieszonych kładek dla pieszych o niskich wartościach częstotliwości drgań własnych;

- zaznaczyć należy, iż zaproponowane model obciążeń dynamicznych (1), (2), (3) mają zastosowanie w przedziale częstotliwości przysiadów $f_{s q}=1,20-$ $2,80 \mathrm{~Hz}$ z podziałem na dwa zakresy częstotliwości $f_{s q, 1}=1,20-1,60 \mathrm{~Hz}$ oraz $f_{s q, 2}=1,60-2,80 \mathrm{~Hz}$. Podczas wstępnych analiz stwierdzono możliwość zastosowania modelu (3) dla $f_{s q}>2,80 \mathrm{~Hz}$. Ocena skuteczności działania i możliwości wykorzystania modelu (3) dla $f_{s q}>2,80 \mathrm{~Hz}$ wymaga przeprowadzenia dalszych badań $V G R F$ w przedziale częstotliwości przysiadów $f_{s q}=2,80-$ $3,50(4,00) \mathrm{Hz}$ oraz testów i analiz poprawności i skuteczności działania modelu;

- dalszych badań i analiz wymaga określenie warunków wykonywania przysiadów z możliwością prostowania nóg podczas końcowego etapu fazy wznoszenia oraz dookreślenie granicznej wartości częstotliwości przysiadów wykonywanych z prostowaniem nóg. W opracowanych modelach (1) i (2) za wartość graniczną częstotliwości umożliwiającej prostowanie nóg w końcowym etapie fazy wznoszenia przyjęto $f_{s q}=1,60 \mathrm{~Hz}$. Częstotliwość ta może być wyższa i ogólnie zależna jest od indywidualnych predyspozycji osoby wykonującej przysiady oraz od częstotliwości i głębokości przysiadów; 
- wykonane analizy wskazują, iż krzywe $V G R F$ wyznaczone za pomocą model obciążenia (5) zaproponowanego w pracy [2] dobrze odzwierciedlają przebieg $V G R F$ w przedziale częstotliwości przysiadów $f_{s q}=1,80-2,40 \mathrm{~Hz}$ (por. rys. 7.). Określenie możliwości wykorzystania modelu (5) dla innych (niższych i wyższych) wartości częstotliwości przysiadów wymaga dalszych analiz. Wymagane może być dostrojenie parametrów modelu dla różnych przedziałów częstotliwości przysiadów;

- porównanie wyników analiz numerycznych i badań terenowych przedstawione w tab. 1 pozwala stwierdzić poprawność i wysoką skuteczność modeli (1), (2), (3), (5) zastosowanych do wyznaczenia wartości $V G R F$ oraz odpowiedzi dynamicznej kładek dla pieszych. W analizach numerycznych uzyskano bardzo dużą zgodność obliczonych wartości przyspieszeń drgań konstrukcji $\mathrm{z}$ wartościami przyspieszeń drgań pomierzonymi w trakcie badań terenowych;

- zauważyć warto, iż model obciążenia (3) zaproponowany dla $f_{s q}>1,60 \mathrm{~Hz}$ jest modelem nieskomplikowanym i łatwym do wykorzystania, pozwalającym bardzo dokładnie odtworzyć przebieg VGRF oraz oszacować wartość przyspieszeń drgań konstrukcji w istotnym przedziale częstotliwości pionowych drgań własnych kładek dla pieszych $f_{v}=2,00-2,60 \mathrm{~Hz}$;

- weryfikacja poprawności i skuteczności działania modeli (1), (2), (3), (5) w szerokim przedziale częstotliwości przysiadów $f_{s q}=1,20-2,80 \mathrm{~Hz}$ (szczególnie w przedziale dla $f_{s q}<2,00 \mathrm{~Hz}$ ) wymaga wykonania dalszych badań i analiz numerycznych kładek dla pieszych i/lub innych konstrukcji o odpowiednich parametrach dynamicznych.

\section{Literatura}

[1] Schoenfeld B.J.: Squatting kinematics and kinetics and their application to exercise performance, NSCA Journal Strength and Conditioning Research, Vol. 24, No. 12, 2010, pp. 3497-3506.

[2] Żółtowski K.: Pieszy na kładkach: obciążenia i odpowiedź konstrukcji, Wydawnictwo Politechniki Gdańskiej, Monografia 82, 2007.

[3] Pańtak M.: Dynamic characteristics of medium span truss, cable-stayed and suspension steel footbridges under human-induced excitation, Dolnośląskie Wydawnictwo Edukacyjne, Proc. of $4^{\text {th }}$ International Conference "Footbridge 2011", 2011, pp. 1209-1214.

[4] Bachmann H., Ammann W., Deischl F. et al.: Vibration problems in structures: practical guidelines, Birkäuser Verlag, 1995. 


\section{MODELLING OF THE DYNAMIC LOADS IN THE FORM OF SQUATS ON FOOTBRIDGES}

\section{S u m m a r y}

Dynamic forces generated by moving persons can lead to excessive vibration of the long span, slender and light-weight structure such as floors, stairs, stadium stands and footbridges. These dynamic forces are generated during walking, running, jumping and rhythmical body swaying in vertical or horizontal direction etc. One of the important type of dynamic loading of a susceptible and light-weight structures can be the ground reaction forces generated during rhythmically repeated squats. In the paper the load models of the ground reaction forces generated during partial squats have been presented. Elaborated models was compared to the forces measured during laboratory tests carried out by author in wide range of frequency using force platform. Moreover, the load models were initially validated during dynamic numerical analyses and dynamic field tests of the exemplary footbridges.

Keywords: squats, vibrations, susceptibility, ground reaction forces, dynamic response, footbridges, floors, stadium stands

Przestano do redakcji: 27.04.2017 $r$.

Przyjęto do druku: 01.09.2017 r. 